\title{
BORNEO FAUNA ANXIETIES
}

\section{By Tom IIsRrisson, D.S.O., Curator, Sarawak Museum}

So much of Borneo is still uninhabited by man-it must be the least densely populated part of tropical Asia-that it is difficult to imagine its wild fauna being endangered. Much the larger part of the island is still jungle, visited only (if at all) by nomadic groups. But a few species, conspicuous and attractive to humanity for size, food, medicine or beauty, are to-day in danger in all the four territories (Indonesian Borneo, and the British western section comprising North Borneo, Sarawak and Brunci).

Far the most serious is the case of the two-horned rhinoceros, Didermocerus sumatrensis. It is not even especially reassuring that it occurs elsewhere in Indonesia, since the old Dutch game laws, inadequate as they were, are neither being properly enforeed nor replaced in the remoter areas. Twenty years ago the rhino was still common over Borneo. Within living memory it came down into village arcas and did damage in the ricefields of the Kelabit plateau. Now there are probably not more than two or three in Sarawak; none in Brunei; some reported in east of North Borneo ; and a handful-now heavily threatenedin Indonesian territory.

The rhino has been hunted to near extinction in Borneo mainly for its horn, hooves and other appendages, which are highly valued by the Chinese as alleged aphrodisiacs. The introduction of fircarms to the inland peoples in this century accelerated the killing of an animal which is tough (for blowpipe poison), scentless to most hunting dogs, shy and with good sense of hearing; but very short-sighted and leaving a trail of mudwallows, stripped bushes and droppings which can be followed even weeks later. It is now theoretically protected in all territories. One shot since $\mathbf{1 9 4 5}$ led to a conviction (Sibu area). I have seen the tracks of two in very wide jungle travels since 1945. But the last was in the forties, and an old track. The difficulty is to enforce any such law in this huge area. Nowhere in Borneo is there a separately organized game service or other effective protection enforcement.

The orang-utan, Pongo, now also gives cause for anxiety. Large numbers are exported from Indonesian territory and the present situation enables people in British territory to export an orang without offence if they can swear it came from over the border! This pleasant ape has a very restricted (swamplowland) habitat in areas surrounded by Dyaks and other 
indigenous people. It is easy to catch the young by killing the mothers and this is the normal practice. Accounts even as late as the start of this century describe the maias (a local name) as common where it is now unknown. Indeed, the slaughter described; with complacency, by even such thoughtful visitors as Alfred Russell Wallace and Beccari, leaves little ground for wonder at its present status. This threat to the orang is caused almost entirely by American and European demands for zoos and circuses. Chinese and local people have no interest in a dead orang-utan.

Third is the wild ox, or banteng, Bos banteng, a very pretty chestnut beast with white socks. Here the locals are fully responsible; no one else is interested; the meat is poor and there are no alleged gonadal influences. The Dyaks hunt it for two reasons. First because it does occasionally damage crops, and secondly for the hell of it-in the old head-hunter mood! 'There are still quite a lot about, notably in the strange grassland plains of the upper Bahau, main tributary of the great Batang Kayan river on the Indonesian border. Here they seem to have interbred with local domesticated zebu cattle. But, again, shotguns (and expanding population) are speeding up destruction of a species which likes fairly accessible country, secondary jungle and river lines, though it will also come into the open or roam in virgin jụngle.

If the government of North Borneo had been correct in depicting the big black and white Malayan tapir on its stamps, it would indeed be extinct; but this was a philatelic error. Elephant are only feral. 'Tigers, probably once present, went out prehistorically. The unique proboscis monkey, Nasalis larvatus, is extending its (sub-coastal) range under protection. Fortunately it is much less easy to take alive than the orang-utan and is poor eating. Sambar and barking deer and two forms of mouse deer, Tragalus, are abundant.

No other mammal seems to be in much danger at present. Most are small, many shy or nocturnal. But an all-round decrease of animals in accessible areas cannot be ignored.

The increased felling of jungle in shifting cultivation is also a factor, though a surprising number of the more interesting mammals, c.g. tree-shrews and tarsier, seem able to adapt themselves quite readily to secondary jungle.

Unfortunately, Borncans will cat almost anything, c.g. gibbons, honey bear, pythons and crocodiles, except man and certain cuckoos, Centropus. They will kill anything-clouded leopard for their skins, helmeted hornbills for their casques, 
paradise flycatchers for their superb silver tails, jewel thrushes for their children to play with the lovely bodies.

The specially edible pheasants particularly attract local hunters. Bulwer's pheasant, Lobiophasis bulweri, is, I suspect, declining; probably it never was common. The spendid Argus, $A$. grayi, which by its long call makes itself conspicuous yet offers a challenge of cunning movement to the hunter, is growing scarcer. The Bornean peacock pheasant, Polyplectron, is hardly known and perhaps ever occurred only in one limited area of the south-cast. The total protection of Bornean Phasianidae would seem desirable.

'Two birds of small islands off the coast appear to be in grave risk. One, the silvery wood pigeon, Columba argentea, indeed appears to have been exterminated many years ago from its only known Borncan west coast habitat, Pulau Burong ("Bird Island") by-I am ashamed to say-a collector from the Sarawak Museum. As a result, we have the grim satisfaction of a fine series all taken in one week. As Curator, I have been able to make some amend by actively protecting the related and strictly island, pied imperial pigeon (nutmeg fruit pigeon), Myristicivora bicolor, which has clearly increased in the past decade on the Turtle Islands off the south-west coast.

The other endangered islander is the interesting Megapode, Megapodius treycinct cumingi, which occurs only, in North Borneo.

Two birds of prey are in danger. The fine white-breasted sea cagle, IIaliaetus leucogaster, always needing a wide feeding-zone along the coast, is being potted at by new-style sportsmen. Unfortunately, as well as taking mainly sca-snakes and fish, it likes fowls ; one ate six fantails of mine, newly established on Talang Talang Island, in as many days! I have two sea eagles alive now, both brought in wounded-one is being hand-fed with cut-fish. The sea-eagle population cannot long stand this pressurc.

The other cagle in danger is the black and white bat eagle, Machaerhampus alcinus, which Captain Delacour describes as "a curious crepuscular hawk, fecding on bats. Powerful flight. Difficult to sec . . ." It is actually easy to sec at dusk in cave mouths. Pcople are alleged to have been encouraged to shoot them here on the ground that these eagles also eat birds' nest swiftlets, Collocalia. If they do, these swiftlets are in such tremendous numbers that it seems good natural selection for some to be preyed upon. In the few places that this queer and rare cagle frequents in Borneo, it has become scarcer. 
Not even the great limestone caves of Niah support above two pairs ; but they support at least a million swiftlets and probably even more bats.

Finally two reptiles deserve mention. The edible or green turtle, Chelonia mydas, is not killed in Borneo, only its eggs are collected. In Sarawak we now have a long-term programme for transplanting and rearing baby turtles beyond the "soft" stage, when those that reach the sea are promptly taken by sharks and other fish. It may be that, before long, this massive chunk of flesh will have a world reservoir here? We hope so.

The other reptile is the earless monitor, Lanthonotus borneensis, described from a Sarawak specimen in 1878, which remains one of the rarest of reptiles in world collections. This is a case where further study may disclose a specialized habitat-or recent extinction ? $\Lambda$ picture of the lizard on prominent display in the Sarawak Museum for some years has failed to produce recognition from a single one of the many thousand Borncan visitors. 